\title{
TUMOR-INFILTRATING CD4+ T LYMPHOCYTES IN EARLY BREAST CANCER REFLECT LYMPH NODE INVOLVEMENT
}

Alexandre Henrique Macchetti, ${ }^{a}$ Heitor Ricardo Cosiski Marana, ${ }^{a}$ João Santana Silva, ${ }^{b}$ Jurandyr Moreira de Andrade, ${ }^{a}$ Alfredo Ribeiro-Silva, ${ }^{c}$ and Sérgio Bighetti ${ }^{a}$

\begin{abstract}
Macchetti AH, Marana HRC, Silva JS, Andrade JM de, Ribeiro-Silva A, Bighetti S. Tumor-infiltrating CD4+ T lymphocytes in early breast cancer reflect lymph node involvement. Clinics. 2006;61(3):203-8.
\end{abstract}

BACKGROUND: The role of immune system in the pathogenesis and progression of breast cancer is a subject of controversy, and this stimulated us to investigate the association of the immunophenotype of tumor-infiltrating lymphocytes in early breast cancer with the spread of tumor cells to axillary lymph nodes.

METHODS: Tumor samples from 23 patients with early breast cancer from the Department of Gynecology and Obstetrics of Ribeirão Preto Medical School (USP) were obtained at the time of biopsy and submitted to an enzyme-digestion procedure for the extraction of tumor-infiltrating lymphocytes. The lymphocytes extracted were analyzed by dual-color flow cytometry with monoclonal antibodies in these combinations: CD3 FITC/CD19 PE, CD3 FITC/CD4 PE, CD3 FITC/CD8 PE, and CD16/56 PerCP, which are specific for immunophenotyping of $\mathrm{T}$ and $\mathrm{B}$ lymphocytes, helper and cytotoxic $\mathrm{T}$ lymphocytes, and natural killer (NK) cells. The mean percentage of these cells was used for comparing groups of patients with or without lymph node metastasis.

RESULTS: The mean value for T-lymphocyte infiltration was $24.72 \pm 17.37 \%$; for B-lymphocyte infiltration, $4.22 \pm 6.27 \%$; for NK-cell infiltration, $4.41 \pm 5.22 \%$, and for $\mathrm{CD}^{+}{ }^{+}$and $\mathrm{CD} 8^{+}$T-lymphocyte infiltration, $12.43 \pm 10.12 \%$ and $11.30 \pm 15.09 \%$, respectively. Only mean values of $\mathrm{T}-$ and $\mathrm{CD} 4^{+} \mathrm{T}$-lymphocyte infiltration were higher in the group of patients with lymph node metastasis, while no differences were noted in the other lymphocyte subpopulations.

CONCLUSION: The association of tumor-infiltrating $\mathrm{CD}^{+}$T lymphocytes with lymph node metastasis suggests a role for these cells in the spread of neoplasia to lymph nodes in patients with early breast cancer.

KEYWORDS: Breast cancer. Flow cytometry. Lymphocytes. CD4+ T lymphocytes. Natural killer cells.

\section{INTRODUCTION}

Breast cancer is the most common neoplasm in women, and several studies have documented that these tumors are infiltrated by a heterogeneous population of immune cells,

aDepartment of Gynecology and Obstetrics, Breast Service, Ribeirão Preto Medical School, University of São Paulo - São Paulo/SP, Brazil.

bDepartment of Immunology and Biochemistry, Ribeirão Preto Medical School, University of São Paulo - São Paulo/SP, Brazil.

'Department of Pathology, Ribeirão Preto Medical School, University of São Paulo - São Paulo/SP, Brazil.

Email: ahmacchetti@yahoo.com.br

Received for publication on February 04, 2006.

Accepted for publication on February 20, 2006. consisting of different proportions of T cells, B cells, natural killer (NK) cells, and macrophages. ${ }^{1-4}$ Despite the presence of the immune response, many breast tumors progressively grow and spread, calling into question the role of tumor-infiltrating leukocytes in the tumor microenvironment. $^{5}$

There is no definitive conclusion regarding the efficacy of $\mathrm{T}$ cell-dependent immune mechanisms or regarding the correlation between the extent and type of lymphocyte infiltration and the tumor progression in most subtypes of carcinoma of the breast. ${ }^{4,5}$ These interrelationships could be considered to be important in view of the role played by the immune system in the pathogenesis and progression of the breast cancer. ${ }^{4}$ 
Previous studies have shown that the function of tumorinfiltrating lymphocytes is impaired by inhibitory cytokines, ${ }^{6}$ increased regulatory $\mathrm{T}$ lymphocyte activity, ${ }^{7}$ tumor cell MHC molecule alterations, ${ }^{8}$ and aberrant Fas ligand expression, ${ }^{9}$ among others.

Nodal status as determined by pathologic examination of lymph nodes has repeatedly been shown to be the single most important predictor of survival in breast cancer. Even patients with very small tumors and minimal involvement of a single axillary node have a significantly worse prognosis compared with patients with no axillary node involvement; there is a direct relationship between the number of involved axillary nodes and the risk for distant recurrence..$^{10,11}$

Collectively, these findings have led to increased interest in the role of tumor-infiltrating leukocytes in the regulation of tumor development. In our study, we analyzed by flow cytometry the tumor-infiltrating leukocytes of breast cancer patients with $\mathrm{T} 1$ to $\mathrm{T} 2$ breast tumors in an attempt to correlate phenotypical markers of tumor-infiltrating leukocytes with axillary lymph node status.

\section{PATIENTS AND METHODS}

\section{Patient population}

During the years 2003 and 2004, a consecutive series of 23 patients at the Department of Gynecology and Ob- stetrics of the Ribeirão Preto Medical School who presented with invasive breast carcinoma were included in the study for immunophenotyping the tumor-infiltrating lymphocytes. In all patients, tumor size was no larger than $50 \mathrm{~mm}$ and was strictly confined to breasts, without distant metastasis; cases with involvement of skin, hypodermis, or pectoral muscles or with deep fixation were excluded. All patients included in this study underwent curative surgery plus axillary lymph node dissection, and none of these patients had received preoperative antitumor therapy. The clinical and pathological characteristics of patients included for the immunophenotypic studies are summarized in Table 1.

Informed consent, approved by the Ethics Committee of the Ribeirão Preto Medical School Hospital, was obtained from patients for collecting the material in this study (Process HCRP no 2519/2003).

\section{Processing of tumor biopsy and preparation for flow cytometry analysis}

Samples of the primary tumor from the 23 patients were obtained aseptically at the time of biopsy. The main bulk of each tumor was sent for routine histology. A block of tumor measuring 5 x $5 \mathrm{~mm}$ fresh from the operating room was dissected away from necrotic and fatty tissue, minced into 1 to $3-\mathrm{mm}^{3}$ chunks using sterile forceps and a scalpel, and placed in sterile RPMI 1640 (Sigma, Saint Louis, MO),

Table 1 - Clinical and pathological characteristics of patients with breast cancer

\begin{tabular}{|c|c|c|c|c|c|c|c|}
\hline Case & Age & Tumor Grade & Tumor Size $(\mathrm{cm})$ & TNM & Stage & Lymph node status ${ }^{1}$ & Hormone status \\
\hline 1 & 51 & I & 3.5 & T2N0M0 & IIA & $3 / 25$ & Post \\
\hline 2 & 74 & I & 4.5 & T2N0M0 & IIA & $0 / 19$ & Post \\
\hline 3 & 44 & I & 2.0 & T1N2M0 & IIIA & $7 / 33$ & Pre \\
\hline 4 & 75 & II & 4.5 & $\mathrm{~T} 2 \mathrm{~N} 1 \mathrm{M} 0$ & IIB & $0 / 16$ & Post \\
\hline 5 & 70 & II & 2.0 & T1N0M0 & I & $0 / 18$ & Post \\
\hline 6 & 80 & III & 4.0 & $\mathrm{~T} 2 \mathrm{~N} 1 \mathrm{M} 0$ & IIB & $13 / 22$ & Post \\
\hline 7 & 69 & I & 1.0 & T1N0M0 & I & $0 / 18$ & Post \\
\hline 8 & 90 & II & 1.6 & T1N0M0 & I & $0 / 21$ & Post \\
\hline 9 & 71 & Mucinous & 2.5 & T2N0M0 & IIA & $0 / 15$ & Post \\
\hline 10 & 45 & Mucinous & 3.0 & T2N0M0 & IIA & $3 / 12$ & Pre \\
\hline 11 & 59 & II & 2.5 & T2N0M0 & IIA & $1 / 17$ & Post \\
\hline 12 & 64 & I & 1.8 & T1N0M0 & I & $0 / 28$ & Post \\
\hline 13 & 53 & I & 3.0 & T2N0M0 & IIA & $0 / 17$ & Post \\
\hline 14 & 40 & I & 3.0 & T2N0M0 & IIA & $1 / 13$ & Pre \\
\hline 15 & 58 & III & 3.0 & $\mathrm{~T} 2 \mathrm{~N} 2 \mathrm{M} 0$ & IIIA & $14 / 28$ & Post \\
\hline 16 & 51 & II & 4.0 & T2N0M0 & IIA & $0 / 23$ & Pre \\
\hline 17 & 50 & II & 2.0 & T1N0M0 & I & $12 / 27$ & Pre \\
\hline 18 & 48 & II & 2.0 & T1N1M0 & IIA & $4 / 15$ & Post \\
\hline 19 & 42 & I & 1.0 & T1N0M0 & I & $0 / 12$ & Pre \\
\hline 20 & 42 & I & 4.0 & T2N0M0 & IIA & $0 / 12$ & Pre \\
\hline 21 & 63 & II & 2.0 & T1N2M0 & IIIA & $8 / 25$ & Post \\
\hline 22 & 57 & I & 1.5 & T1N0M0 & I & 0/9 & Post \\
\hline 23 & 59 & I & 2.0 & T1N0M0 & I & $0 / 21$ & Post \\
\hline
\end{tabular}

(1) Lymph node status: number of lymph nodes involved by metastasis/total number of lymph nodes

(2) pre: premenopausal; post: postmenopausal 
containing collagenase type IV (1 g/L; Sigma, Saint Louis, MO), hyaluronidase type V (100 mg/mL; Sigma, Saint Louis, MO), and DNAase type IV (30,000 U/L; Sigma, Saint Louis, MO). Tumor digestion was performed for 40 minutes at $37^{\circ} \mathrm{C}$ in a sterile bottle. $10 \mathrm{~mL}$ of enzyme medium was added per $3 \mathrm{~g}$ of tumor chunks. Following the tumor digestion, the single-cell suspension was filtered through a tissue dissociator grid, and the resultant suspension was washed twice and submitted to immunofluorescent staining of cells for flow cytometry. No attempt was made to separate the tumor-infiltrating lymphocytes from the tumor cells, since many cells would be lost, and this might distort the proportions of the various mononuclear cells present within the infiltrate.

\section{Flow cytometry analysis of leukocyte infiltrate}

The surface characteristics were determined by using the following preparations of monoclonal antibodies: CD3 FITC/CD19 PE, CD3 FITC/CD4 PE, CD3 FITC/CD8 PE, and CD16/56 PerCP (Becton Dickinson, Mountain View, CA), which allowed the lymphocytes be phenotyped as $\mathrm{T}$ cells, $\mathrm{B}$ cells, CD $4^{+} \mathrm{T}$ cells, $\mathrm{CD} 8^{+} \mathrm{T}$ cells, or NK cells, respectively. A $10 \mathrm{~mL}$ sample of a phycoerythrin (PE)-, fluorescein-isothiocyanate (FITC), or peridin-clorophyll-protein (PerCP)-conjugated antibody was added to $10^{6}$ cells in $100 \mathrm{~mL}$ of phosphatebuffered saline (PBS). After an incubation time of 30 min at $4^{\circ} \mathrm{C}$ in darkness, cells were washed twice and resuspended in $500 \mathrm{~mL} \mathrm{PBS}$ and then analyzed with a FACSort flow cytometer (Becton Dickinson, San Jose, CA). The cell samples were run through the flow cytometer, and 10,000 events were analyzed for each sample using Becton Dickinson's CELL QUEST ${ }^{\mathrm{TM}}$ software on an Apple Mac G3 computer.

Using the forward- and side-scatter (FSC and SSC) properties of lymphocytes in laser light, a gate was drawn around the lymphocytes to exclude tumor cells from further analysis. The relative proportions of the phenotypic subsets were measured using 4-quadrant analysis.

\section{Statistical analysis}

The data of each group were submitted to the normality test of GraphPad Prism (version 3.00) of GraphPad Incorporated (San Diego, USA), and a gaussian distribution of data was verified. Data were expressed as the mean \pm standard deviation, and the 2-tailed unpaired Student $t$ test was used for comparing leukocyte infiltration between groups of patients with different lymph node status. Statistical significance was defined as $P<0.05$.

\section{RESULTS}

All patients were treated by lumpectomy with axillary lymph node dissection or modified radical mastectomy in accordance with our management protocol. The patients were women between 40 and 90 years of age (mean and median were 58 years) and included 7 premenopausal and 16 postmenopausal women. According to the pathological TNM classification of cancer staging, 11 of 23 tumors were classified as T1, and 12 of 23 as T2. Lymph node metastasis as determined by histological examination was noted in 10 of 23 cases, with the remaining 13 patients being lymph node negative.

Histologically, 21 of 23 patients had tumors classified as infiltrating ductal carcinoma without special features, while the remaining 2 were classified as mucinous. Tumors with histology of ductal carcinoma were graded according to the Bloom and Richardson grading system, ${ }^{12}$ and there were a total of 11 ductal carcinomas classified as grade I, 8 as grade II, and 2 as grade III.

The mean value for T-lymphocyte infiltration $\left(\mathrm{CD}^{+}\right.$ cells) was $24.72 \pm 17.37 \%$; for B-lymphocyte infiltration (CD19+ cells), $4.22 \pm 6.27 \%$; for NK cell-infiltration $\left(\mathrm{CD} 16^{+} / \mathrm{CD}^{2} 6^{+}\right.$cells $), 4.41 \pm 5.22 \%$; and for $\mathrm{CD}^{+}$and $\mathrm{CD} 8^{+}$T-lymphocyte infiltration $\left(\mathrm{CD}^{+} / \mathrm{CD}^{+}{ }^{+}\right.$and $\mathrm{CD}^{+} /$ $\left.\mathrm{CD}^{+}\right), 12.43 \pm 10.12 \%$ and $11.30 \pm 15.09 \%$, respectively.

Comparing the two groups of patients-those with a presence vs those with an absence of lymph node metastasis-there was a statistically significant difference between groups regarding the mean values of T-lymphocyte and $\mathrm{CD}^{+} \mathrm{T}$-lymphocyte infiltration $(15.35 \pm 2.36 \%$ and 8.41 $\pm 6.22 \%$ with absence of lymph node metastasis vs 36.90 $\pm 18.60 \%$ and $17.64 \pm 12.05 \%$ with presence of lymph node metastasis, $P=0.001$ and $P=0.02$, respectively) (Table 2 ), indicating an association between infiltration by $\mathrm{CD}^{+}$ $\mathrm{T}$ cells and axillary metastasis. There were no statistically significant differences between the means of other lymphocyte subsets for these groups (Table 2).

Table 2 - Subpopulations of Immunocytes in Tumor Tissue from Breast Carcinoma Specimens with Respect to Lymph Node Involvement $\mathrm{a}^{\mathrm{a}, \mathrm{b}}$

\begin{tabular}{lll}
\hline Subpopulations & $\begin{array}{l}\text { Positive lymph } \\
\text { node metastasis }\end{array}$ & $\begin{array}{l}\text { Negative lymph } \\
\text { node metastasis }\end{array}$ \\
\hline T lymphocyte & $36.90 \pm 18.60^{\text {b.d }}$ & $15.35 \pm 8.51$ \\
B lymphocyte & $6.77 \pm 8.42^{\text {b.c }}$ & $2.51 \pm 3.05$ \\
CD4+ T cell & $17.64 \pm 12.05^{\text {b.e }}$ & $8.41 \pm 6.22$ \\
CD8+ T cell & $17.89 \pm 11.50^{\text {b.c }}$ & $13.25 \pm 15.20$ \\
NK cell & $4.70 \pm 6.6^{\text {b.c }}$ & $4.18 \pm 4.10$
\end{tabular}

a. All data are expressed as media percentages followed by standard deviation; b. $P<0.05$; c. $P>0.05$; d. $P=0.001$; e. $P=0.02$ 


\section{DISCUSSION}

In human breast cancer as well as in other solid tumors, isolating tumor-infiltrating lymphocytes is difficult. In the current study, we used dual-flow cytometry for accurate detection of selected lymphocyte subsets, especially the subpopulations of $\mathrm{CD}^{+}$tumor-infiltrating lymphocytes after enzyme-digestion method. In our study, the immunophenotyping of cell types revealed a familiar subdivision of lymphocytes. The tumor-infiltrating lymphocytes, like peripheral blood lymphocytes, consisted mainly of $\mathrm{T}$ cells expressing the $\mathrm{CD} 3$ antigen, and there was a relative paucity of tumor-infiltrating B lymphocytes and NK cells. The mechanisms by which $\mathrm{T}$ cells cause tumor elimination include direct lysis of tumor, recruitment of host cells that have a cytotoxic function, or secretion of cytokines that are either cytotoxic toward tumor or affect the tumor vasculature. ${ }^{14-18}$ Despite findings that the T-cell immune response can kill tumors in situ, this response is frequently ineffective in eliminating the tumor. ${ }^{14-18}$

There was little evidence of effectual action of tumorinfiltrating B lymphocytes against cancer. Few proteins expressed by tumor cells are truly tumor-specific; most antibodies produced will likely be directed against autoantigens, with a small percentage against tumor-specific antigens. ${ }^{4-6,14}$ Another set of lymphocytes, NK cells, seems to have tumoricidal activity that is not dependent on prior sensitization. These are components of innate immunity, and pattern-recognition receptors and other cellsurface molecules are used to directly detect tumors. ${ }^{15-17}$ Natural killer cells also monitor for the loss of MHC class I molecules from the surface of the tumor cells, which commonly occurs during carcinogenesis. ${ }^{15,16,18}$ Most breast cancers display diminished MHC class I expression, making them particularly vulnerable to NK cell-mediated killing. However, our data showed that breast tumors are poorly infiltrated by NK cells compared to T cells, and other studies have shown that the loss of MHC is associated with Tcell infiltration instead of with NK-cell infiltration. ${ }^{15,18}$

Adaptive immunity is mediated by antibodies and by $\mathrm{CD}^{+}$and $\mathrm{CD}^{+}{ }^{+} \mathrm{T}$ cells, and it usually exploits an indirect pathway, termed cross-priming, to achieve initial recognition of cancers. ${ }^{15-17}$ Accordingly, $\mathrm{CD}^{+}{ }^{+}$and $\mathrm{CD} 8^{+} \mathrm{T}$ cells react with $\mathrm{MHC}$-restricted tumor peptides derived from mutated proteins, aberrantly expressed gene products, and normal differentiation antigens that are produced by the cancer cells. Although specific immunity mediated by cytolytic $\mathrm{T}$ lymphocytes might have an anticancer role, the tumors escape from T-cell-based immune surveillance using various mechanisms, such as down regulation, mutation, or loss of HLA class I molecules. ${ }^{3-6,15-18}$ In patients with lymph node metastasis, an increased mean percentage of tumor-infiltrating $\mathrm{CD} 4^{+} \mathrm{T}$ cells, but not $\mathrm{CD} 8^{+} \mathrm{T}$ cells, was seen. The relationship between tumor stage and Tlymphocyte infiltration has previously been demonstrated in patients with prostate, gallbladder, renal, colorectal, and breast cancer. ${ }^{6,19-21}$

Nodal status as determined by pathologic examination of lymph nodes has repeatedly been shown to be the single most important predictor of survival in breast cancer. ${ }^{11,12}$ Association between the intensity of infiltration by T CD4 $4^{+}$ lymphocytes and positive axillary lymph nodes has been demonstrated, and these patients had a worse prognosis. ${ }^{3-}$ $6,22,23$ Wong et $\mathrm{al}^{23}$ demonstrated that the tumor-infiltrating lymphocytes of patients with positive lymph nodes had a greater tumoricidal activity, but this may be reflect the need for a more intense immune response in patients with tumorinvolved nodes or that in a significant subgroup of breast cancer patients, tumor-infiltrating lymphocytes might create a favorable environment for the spreading of malignant cells.

Several findings of previous studies could explain this association with worse prognosis. The tumor-infiltrating lymphocytes are able to produce and release vascular endothelial growth factor (VEGF) and basic fibroblastic growth factor, which can induce lymphangiogenesis and angiogenesis and consequently could permit the dissemination of cancer cells through lymphatics to regional lymph nodes. ${ }^{24-28}$

Bernstein et $\mathrm{al}^{29}$ demonstrated that the aromatase (CYP19) gene is presented in tumor-infiltrating lymphocytes, and the presence of local oestrone formation could have some functional significance for the estrogendependent growth of breast cancer tissue, creating favorable environment for cancer cells. The presence of tumor-infiltrating lymphocytes in breast carcinomas and production of potentially immunoinhibitory cytokines such as IL-4, IL10 , and TGF-2 1 has been demonstrated; this production by tumor-infiltrating lymphocytes in breast cancers exceeded that detected in benign breast lesions, suggesting a role for tumor-infiltrating lymphocytes in immunosuppression, creating a mechanism of immune escape for the tumor. ${ }^{30}$

The matrix metalloproteinases are associated with the invasive properties of tumor cells, owing to their ability to degrade all major protein components of the extracellular matrix and basement membranes, stimulate cell proliferation, and modulate angiogenesis, ${ }^{31}$ and it has been shown that breast cancer cells can induce expression of matrix metalloproteinase-9 (MMP-9) in fibroblasts by tumor cellderived TNF- $\alpha$ and TGF- $\beta .^{31}$ The lymphocyte invasion of a tumor mass is of crucial importance in the host's defense against the developing neoplasm, and has been shown that 
T lymphocytes constitutively produce small amounts of MMP-9, a finding supported by the normal leukocyte migration from the vascular compartment to sites of inflammation. ${ }^{33}$ However, Owen et al, ${ }^{34}$ evaluating the MMP-9 production by $\mathrm{T}$ cells from normal and mammary tumorbearing mice, have shown that mammary tumor cells produce MMP-9 and the T cells from tumor-bearing animals constitutively produce higher levels of this enzyme and correlate with tumor growth. These observations suggest that tumor-infiltrating lymphocytes, regarded as evidence of a protective immune response against tumors, can promote angiogenesis and microvasculature remodeling. Thus, is tempting to speculate that these factors may promote neoplastic progression and dissemination throughout the tumor site.

Our finding of an association of higher levels of tumorinfiltrating $\mathrm{CD}^{+} \mathrm{T}$ lymphocytes with lymph node involvement by metastasis may be explained by more recent studies showing that tumor-infiltrating lymphocytes are associated with vasculogenesis, immunoinhibitory cytokines, and intratumoral estrogen conversion. Although we recognize that the findings to date are based on a limited number of patients, our observations are supported by previous studies and could contribute importantly to the understanding of mechanisms that govern the interactions between lymphocytes and breast cancer.

\section{RESUMO}

Macchetti AH, Marana HRC, Silva JS, Andrade JM de, Ribeiro-Silva A, Bighetti S. Linfócitos $\mathrm{T} \mathrm{CD}^{+}$tumor infiltrantes no câncer de mama inicial refletem envolvimento linfonodal. Clinics. 2006;61(3):203-8.

INTRODUÇÃO: O papel do sistema imunológico na patogênese e progressão do câncer de mama ainda é controverso, e isto nos estimulou a verificar a associação do imunofenótipo dos linfócitos tumor infiltrantes do câncer de mama inicial com a disseminação de células tumorais para os linfonodos axilares.

MÉTODOS: Amostras tumorais de 23 pacientes com câncer de mama inicial do Departamento de Ginecologia e Obstetrícia da Faculdade de Medicina de Ribeirão Preto (USP) foram obtidas no momento da biópsia e depois submetidas ao método de digestão enzimática para a extração dos linfócitos tumor infiltrantes. Os linfócitos extraídos foram analisados por citometria de fluxo com anticorpos monoclonais nas seguintes combinações: CD3 FITC/CD19 PE, CD3 FITC/CD4 PE, CD3 FITC/CD8 PE, e CD16/56 PerCP, específicos para imunofenotipagem de linfócitos T e B, linfócitos T helper, linfócitos citotóxicos, e células Natural Killer. Os valores médios destas subpopulações leucocitárias foram comparados entre grupos de pacientes com ou sem metástases linfonodais.

RESULTADOS: O valor médio do infiltrado por linfócitos $\mathrm{T}$ foi $24,72 \pm 17,37 \%$, para o infiltrado por linfócitos B foi $4,22 \pm 6,27 \%$, e para o infiltrado por células Natural Killer foi $4,41 \pm 5,22 \%$, e para o infiltrado por linfócitos $\mathrm{T} \mathrm{CD}^{+}{ }^{+}$e CD8 ${ }^{+}$ foram, respectivamente, $12,43 \pm 10,12 \%$ e $11,30 \pm 15,09 \%$. Os valores médios do infiltrado por células $\mathrm{T}$ e $\mathrm{T} \mathrm{CD} 4^{+}$foram maiores no grupo de pacientes com metástase axilar, enquanto nas outras subpopulações nada foi encontrado.

CONCLUSÃO: A associação dos linfócitos T CD4+ tumor infiltrantes com metástases linfonodais sugere um papel destas células na disseminação das células neoplásicas aos linfonodos dos pacientes com câncer de mama inicial.

UNITERMOS: Câncer de Mama. Citometria de Fluxo. Linfócitos. Células Natural Killer.

\section{REFERENCES}

1. Bosetti C, Malvezzi M, Chatenoud L, Negri E, Levi F, La Vecchia C. Trends in cancer mortality in the Americas, 1970-2000. Ann Oncol. 2005; 16:489-511.

2. Aaltomaa S, Lipponen P, Eskelinen M, Kosma VM, Marin S, Alhava E, et al. Lymphocyte infiltrates as a prognostic variable in female breast cancer. Eur J Cancer. 1992;28A:859-64.
3. Georgiannos SN, Renaut A, Goode AW, Sheaff M. The immunophenotype and activation status of the lymphocytic infiltrate in human breast cancers, the role of the major histocompatibility complex in cell-mediated immune mechanisms, and their association with prognostic indicators. Surgery. 2003;134:827-34. 
4. Vgenopoulou S, Lazaris AC, Markopoulos C, Boltetsou E, Kyriakou V, Kavantzas N, et al. Immunohistochemical evaluation of immune response in invasive ductal breast cancer of not-otherwise-specified type. Breast. 2003;12:172-8

5. Marsigliante S, Biscozzo L, Marra A, Nicolardi G, Leo G, Lobreglio GB, et al. Computerised counting of tumour infiltrating lymphocytes in 90 breast cancer specimens. Cancer Lett. 1999;139:33-41.

6. Pardoll D. Does the immune system see tumors as foreign or self? Annu Rev Immunol. 2003;21:807-39.

7. Reome JB, Hylind JC, Dutton RW, Dobrzanski MJ. Type 1 and type 2 tumor infiltrating effector cell subpopulations in progressive breast cancer. Clin Immunol. 2004;111:69-81.

8. Liyanage UK, Moore TT, Joo HG, Tanaka Y, Herrmann V, Doherty G, et al. Prevalence of regulatory T cells is increased in peripheral blood and tumor microenvironment of patients with pancreas or breast adenocarcinoma. J Immunol. 2002;169:2756-61.

9. Redondo M, Garcia J, Villar E, Rodrigo I, Perea-Milla E, Serrano A, et al. Major histocompatibility complex status in breast carcinogenesis and relationship to apoptosis. Hum Pathol. 2003;34:1283-9.

10. Botti C, Buglioni S, Benevolo M, Giannarelli D, Papaldo P, Cognetti F, et al. Altered expression of FAS system is related to adverse clinical outcome in stage I-II breast cancer patients treated with adjuvant anthracycline-based chemotherapy. Clin Cancer Res. 2004;10:1360-5.

11. Colleoni M, Rotmensz N, Peruzzotti G, Maisonneuve P, Mazzarol G, Pruneri G, et al. Size of breast cancer metastases in axillary lymph nodes: clinical relevance of minimal lymph node involvement. J Clin Oncol. 2005;23:1379-89.

12. Verschraegen C, Vinh-Hung V, Cserni G, Gordon R, Royce ME, Vlastos $\mathrm{G}$, et al. Modeling the effect of tumor size in early breast cancer. Ann Surg 2005;241:309-18.

13. Bloom HJG, Richardson WW. Histological grading and prognosis in breast cancer: a study of 1409 cases of which 359 have been followed for 15 years. Br J Cancer. 1957;11:359-65.

14. Coronella JA, Spier C, Welch M, Trevor KT, Stopeck AT, Villar H, et al. Antigen-driven oligoclonal expansion of tumor-infiltrating B cells in infiltrating ductal carcinoma of the breast. J Immunol. 2002;169:182936.

15. Marincola FM, Jaffee EM, Hicklin DJ, Ferrone S. Escape of human solid tumors from T-cell recognition: molecular mechanisms and functional significance. Adv Immunol. 2000;74:181-273.

16. Diefenbach A, Raulet DH. The innate immune response to tumors and its role in the induction of T-cell immunity. Immunol Rev. 2002;188:921.

17. Dranoff G. Coordinated tumor immunity. J Clin Invest. 2003;111:11168.

18. Moretta A. Natural killer cells and dendritic cells: rendezvous in abused tissues. Nat Rev Immunol. 2002;2:957-64.

19. Ali AA, McMillan DC, Matalka II, McNicol AM, McArdle CS. Tumour T-lymphocyte subset infiltration and tumour recurrence following curative resection for colorectal cancer. Eur J Surg Oncol. 2004; 30:2925 .
20. McArdle PA, Canna K, McMillan DC, McNicol AM, Campbell R, Underwood MA. The relationship between T-lymphocyte subset infiltration and survival in patients with prostate cancer. Br J Cancer 2004 91:541-3.

21. Bromwich EJ, McArdle PA, Canna K, McMillan DC, McNicol AM, Brown $\mathrm{M}$, et al. The relationship between T-lymphocyte infiltration, stage, tumour grade and survival in patients undergoing curative surgery for renal cell cancer. Br J Cancer. 2003;89:1906-8.

22. Treilleux I, Blay JY, Bendriss-Vermare N, Ray-Coquard I, Bachelot T, Guastalla JP, et al. Dendritic cell infiltration and prognosis of early stage breast cancer. Clin Cancer Res. 2004;10:7466-74.

23. Wong PY, Staren ED, Tereshkova N, Braun DP. Functional analysis of tumor-infiltrating leukocytes in breast cancer patients. J Surg Res. 1998;76:95-103.

24. Mor F, Quintana FJ, Cohen IR. Angiogenesis-inflammation cross-talk: vascular endothelial growth factor is secreted by activated $\mathrm{T}$ cells and induces Th1 polarization. J Immunol. 2004;172:4618-23.

25. Nathanson SD. Insights into the mechanisms of lymph node metastasis Cancer. 2003;98:413-23.

26. Chang L, Kaipainen A, Folkman J. Lymphangiogenesis: new mechanisms. Ann N Y Acad Sci. 2002;979:111-9.

27. Peoples GE, Blotnick S, Takahashi K, Freeman MR, Klagsbrun M, Eberlein TJ. T lymphocytes that infiltrate tumors and atherosclerotic plaques produce heparin-binding epidermal growth factor-like growth factor and basic fibroblast growth factor: a potential pathologic role. Proc Natl Acad Sci USA. 1995;92:6547-51.

28. Freeman MR, Schneck FX, Gagnon ML, Corless C, Soker S, Niknejad $\mathrm{K}$, et al. Peripheral blood $\mathrm{T}$ lymphocytes and lymphocytes infiltrating human cancers express vascular endothelial growth factor: a potential role for T cells in angiogenesis. Cancer Res. 1995;55:4140-5.

29. Berstein LM, Larionov AA, Poroshina TE, Zimarina TS, Leenman EE. Aromatase (CYP19) expression in tumor-infiltrating lymphocytes and blood mononuclears. J Cancer Res Clin Oncol. 2002;128:173-6.

30. Camp BJ, Dyhrman ST, Memoli VA, Mott LA, Barth RJ Jr. In situ cytokine production by breast cancer tumor-infiltrating lymphocytes. Ann Surg Oncol. 1996;3:176-84.

31. Folgueras AR, Pendas AM, Sanchez LM, Lopez-Otin C. Matrix metalloproteinases in cancer: from new functions to improved inhibition strategies. Int J Dev Biol. 2002;48:411-24.

32. Stuelten CH, Byfield SD, Arany PR, Karpova TS, Stetler-Stevenson WG Roberts AB. Breast cancer cells induce stromal fibroblasts to express MMP-9 via secretion of TNF- $\alpha$ and TGF- $\beta$. J Cell Sci. 2005;118:214353.

33. Stetler-Stevenson M, Mansoor A, Lim M, Fukushima P, Kehrl J, Marti $\mathrm{G}$, et al. Expression of matrix metalloproteinases and tissue inhibitors of metalloproteinases in reactive and neoplastic lymphoid cells. Blood. 1997;89:1708-15

34. Owen JL, Iragavarapu-Charyulu V, Gunja-Smith Z, Herbert LM, Grosso JF, Lopez DM. Up-regulation of matrix metalloproteinase-9 in T lymphocytes of mammary tumor bearers: role of vascular endothelial growth factor. J Immunol. 2003;171:4340-51. 